\title{
Andrew T. Tsubaki
}

\author{
John D. Swain
}

\begin{abstract}
Andrew Tsubaki's touring productions using nō and kyōgen techniques, his lectures, and his teaching at the University of Kansas and beyond were important avenues for alerting American scholars and students to traditional Japanese theatre forms.

John D. Swain is an assistant professor in the Department of Theatre at California State University-Northridge. His research is on theatre in contemporary Japan, concentrating on theatre by marginalized groups in Japan. He is working on a study of postWorld War II Okinawan theatre within the pressures of American and Japanese cultural and political hegemony. His publications include "Female Bodies Translated across the Strait of Korea: Corporeal Transformation in Chong Wishin's Plays," Japanese Language and Literature 43, no. 2 (2009).
\end{abstract}

One of the more mundane translations Andrew Takahisa Tsubaki (1931-2009) worked on as a cultural conduit between Japan and the rest of the world was preparing a Japanese operating manual for an American-designed unit-built hog sty. The murky details of how to hose down a pig pen are a far cry from scholarship on the rarefied aesthetics of $n \bar{o}$ theatre, but for Tsubaki both $n \bar{o}$ and pig farming were about building connections between Japan and the rest of the world, an endeavor that earned him the Imperial Order of the Sacred Treasure from the Japanese emperor in November 2006.

When Tsubaki left Japan for Canada in 1958, a career as a theatre scholar and transmitter of traditional Japanese theatre forms to Western students did not seem to be on his horizon. As a junior high school English teacher Tsubaki earned a grant for one year of overseas study at the University of Saskatchewan, and persuaded his principal to hold his job open until his return. However, his love of theatre 
combined with the encouragement of his Canadian professors led him to start an MA at Texas Christian University in 1959. It was there, in 1961, that Tsubaki directed his first English language translation of a Japanese play-Mishima Yukio's Aoi no ue (The Lady Aoi, 1954)—and began what was to be his great contribution to theatre scholarship and education. Over the next four decades, Tsubaki devoted himself to teaching Japanese performance forms to people in North America and around the world. He not only introduced them to the fundamentals of traditional Japanese theatre aesthetics, but also trained them in the theories of $n \bar{o}$, kyōgen, and kabuki acting techniques.

Tsubaki's time at Saskatchewan and TCU clarified two things for him: that Canadians and Americans did not know much about traditional Japanese theatre, and neither did he. One of the stories Tsubaki-sensei often told his students at the University of Kansas, where he taught from 1968 to 2000, was how people would ask him about $n \bar{o}$ or kabuki, but he did not know enough to answer their questions. One reason was that in Japan his interest had been on performing contemporary theatre. Modern plays remained his interest while at TCU. Tsubaki wrote his MA thesis there in 1961, under the guidance of Walther Volbach, titled "The Western Influence on the Development of Modern Theatre in Japan." It wasn't until he went to the University of Illinois, Urbana-Champaign, on a full fellowship in 1961 that Tsubaki turned to the study of classical Japanese theatre.

In his second year at Illinois Tsubaki began studying with Joseph W. Scott, a relationship he describes in a series of articles for the Japanese periodical Sōgō geijutsu toshite nō (Nō: The Comprehensive Art, 2001-2009) as defining his life's work. Scott had been in Japan at the end of World War II in the early years of the US Occupation and developed an interest in $n \bar{o}$, then returned to the United States to earn his PhD (Scott 1949). As Scott's teaching assistant, Tsubaki set to work creating an index card database of all 240 known no plays, with plot summaries, character lists, and major properties. Upon completing that, Tsubaki had to create a list of terms characteristic to $n \bar{o}$ and define them in English. It was this task, combined with reading Richard N. McKinnon's PhD dissertation, "Zeami on the Nō: A Study of 15th Century Japanese Dramatic Criticism" (1951), that led to his own PhD topic. Tsubaki narrowed the focus of his dissertation to an analysis of Zeami's aesthetic principle of yūgen. Based on this study, Tsubaki published "Zeami and the Transition of the Concept of Yügen: A Note on Japanese Aesthetics," in the Journal of Aesthetics and Art Criticism in the fall of 1971. This became one of his most important theoretical contributions to the field.

Tsubaki had completed all of his doctoral requirements except 
for the dissertation when he started his first teaching job at Bowling Green State University in 1964. Able to write only during the summer vacation, it was not until 1967 that he finished his dissertation. Perhaps the biggest reason for his slow pace was that in Bowling Green's faculty of two, he not only taught classes, but also was director, designer, and do-it-all for four productions per year. It was with great relief that he landed the job at the University of Kansas in the fall of 1968 (Tsubaki 2002, vol. 7: 15).

Before that, however, he met the Nomura kyoggen family in the fall of 1967 when they came to Bowling Green for performances. This meeting was as important for Tsubaki as the mentoring he received earlier from Scott, because it opened the door into traditional performance training and practice, and Tsubaki would later study both $n \bar{o}$ and kyōgen with Nomura actors. Tsubaki's study of kyōgen, nō, and kabuki translated into teaching and directing traditional forms of Japanese performance at the University of Kansas and around the world. While Leonard Pronko at Pomona College and James R. Brandon at the University of Hawai' $i$ at Mānoa were specializing in producing kabuki, Tsubaki made his major contribution staging kyōgen and nō in English. While Tsubaki's published scholarship adds to our understanding the development of $n \bar{o}$ and kabuki, it is his activities performing and teaching the performance of Japanese traditional theatre forms that is his most important scholarly and educational legacy. Many of the students who went through his classrooms learned the suri ashi of the no walk, Benkei's stylized roppo exit from the kabuki play Kanjinchō (The Subscription List), how the servant Tarōkaja licked the sugar from his fan in the kyoggen play Busu (Sweet Poison), or the rhythms of a nō kodaiko hand drum. These experiences enlarged his students' perceptions of what theatre was and could be. Tsubaki's efforts to learn and transmit the details of classical performance to his students at Kansas and around the world were tireless and thorough.

At Kansas, not only was the faculty bigger than at Bowling Green, but Tsubaki was hired explicitly to develop international theatre studies and Japanese theatre. In the fall of 1969 he directed his first plays at Kansas. They were two postwar Japanese plays by Kinoshita Junji, Akai jinbaori (The Red Tunic, 1947) and Yüdzuru (Twilight Crane, 1950). The summer before, he went back to Japan for the first time in eleven years. While there, he took on the daunting task of learning pieces from kabuki, nō, and kyogen all at the same time-learning kabuki from Nakamura Matagorō, nō from Nomura Shirō, and kyōgen from Nomura Mansaku-all over the span of about four weeks.

Tsubaki's method for success was to record and film every lesson, taking notes as much as he could during the lesson, then return- 
ing home to listen to and view the media again and again, taking additional copious notes. In this manner, he learned the entire dialogue and blocking of the kabuki play Kanjinchō, the shite role for the nō Funa Benkei (Benkei on the Boat), and the dialogue and blocking for three kyōgen plays, Busu, Kamabara (Committing Suicide with a Sickle), and Dondarō (Mr. Dumbtaro; see Fig. 1). In addition, he learned the kyōgen dance pieces Usagi (Rabbit) and Hana no sode (Brocade Sleeves).

In the spring of 1970, the three kyogen plays Busu, Kamabara, and Dondarō became the first productions of traditional Japanese theatre that Tsubaki did at Kansas. Busu and the two dance pieces, Usagi

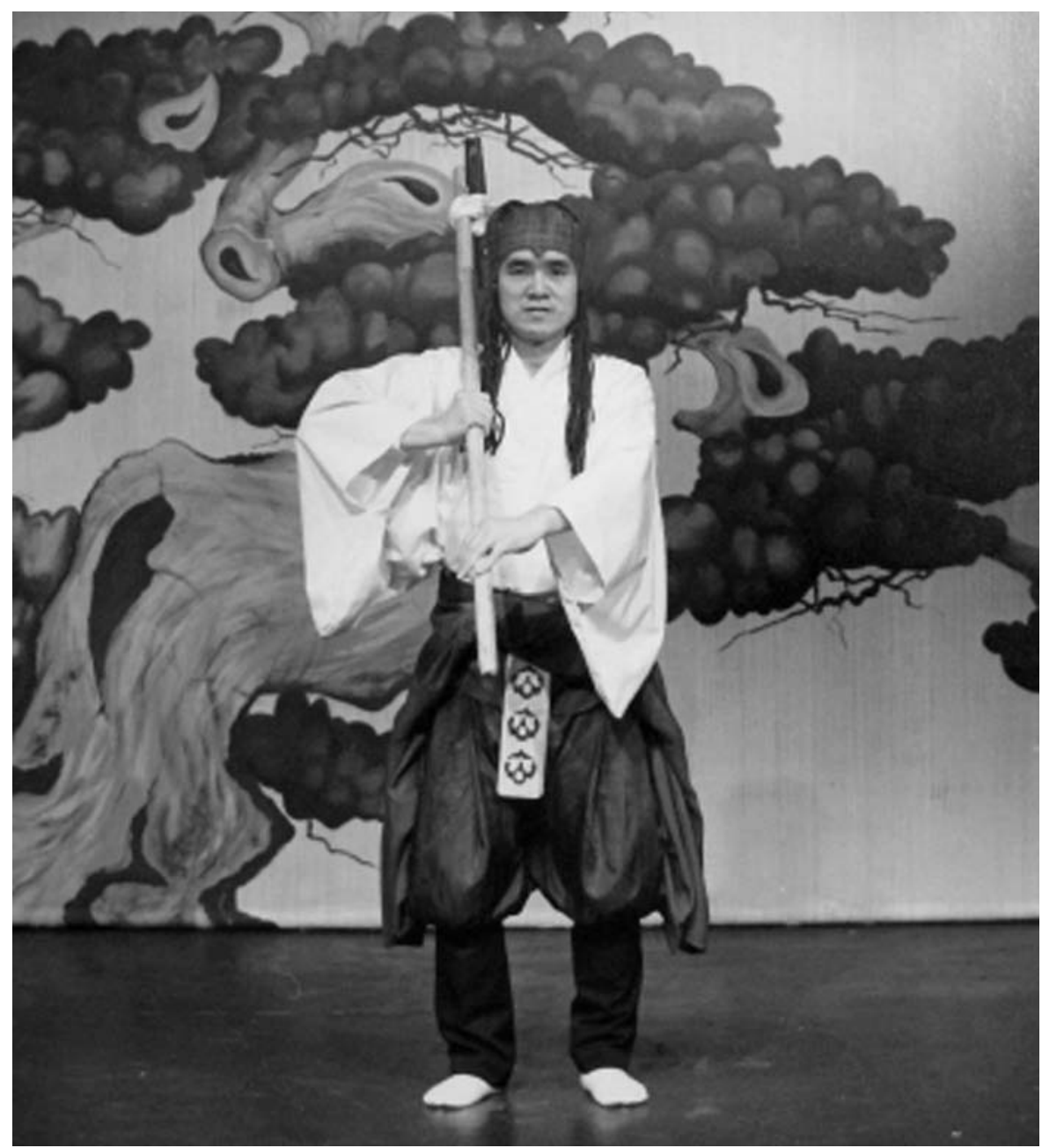

Figure 1. Tsubaki as Dondarō at the University of Kansas, 1970. (Photo: A. T. Tsubaki private collection) 
and Hana no sode, along with the kuse mai dance from Funa Benkei and Benkei's roppo from Kanjinchō, became the core of the Styles of Acting: Classical Japanese course that Tsubaki taught for the next thirty years at Kansas. Over those years, Tsubaki directed a variety of kabuki, no, and kyōgen, but it was kyōgen that gave him the most successful productions-a success that seemed to come from the personal pleasure that was evident whenever he acted or taught the form.

However, it was through kabuki that Tsubaki started to take his instruction beyond the campus of the University of Kansas. In the summer of 1973 he returned to Japan for more practical training and research into the performance conventions of $n \bar{o}$. He refreshed his work on Kanjinchō and made arrangements to be a visiting professor at Carleton College in Northfield, Minnesota. He taught his classical Japanese acting class and directed an English-language production of Kanjinchō at Carleton. It was also through kabuki that Tsubaki began spreading the work of the International Theatre Center at Kansas to other countries. Following a sabbatical in Japan in 1974-1975, he went to Tel Aviv University in Israel as a visiting professor. At Tel Aviv, Tsubaki taught classes in Japanese theatre and produced an evening of kabuki dance.

Kabuki was also a big part of the next phase of performances that

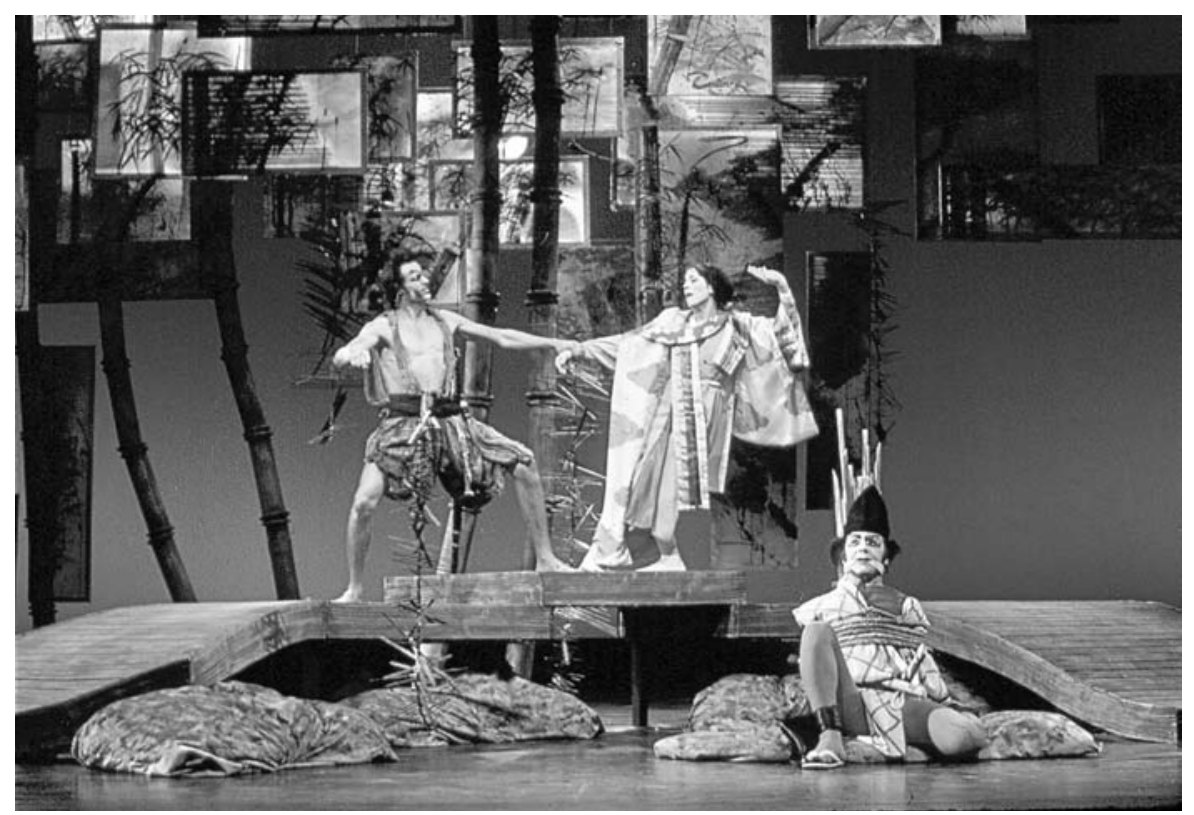

Figure 2. Rashomon at the University of Kansas, 1978. (Photo: University of Kansas, University Theatre Archives) 
Tsubaki began to develop. In 1976, he did a production of Rashomon at Kansas that used kabuki acting techniques. It was his first production to apply traditional Japanese theatre forms to other types of plays. This production was well received, and he revived it at the Missouri Repertory Theatre in Kansas City in 1978 (see Fig. 2), and at the National School of Drama in New Delhi, India, in 1983.

Because Rashomon was adapted for the stage from Kurosawa Akira's film, it had a certain Japanese sensibility at its heart. Applying kabuki techniques was a natural fit to the story set in the Edo era. Because of the success of Rashomon, Tsubaki developed a class for graduate students at Kansas called Advanced Studies in Japanese Classical Acting. The objective of the course was to give students more extended training in classical Japanese forms and to develop a production of a non-Japanese play using adaptations of one or more of the forms. For example, students produced scenes from plays such as Oedipus at Colonus and Macbeth using nō styles. Tsubaki took on the challenge of staging full productions that came out of these workshop classes.

In April 1978, as part of the Kansas University Theatre season, Tsubaki staged his first fully mounted fusion production, The Missing Lamb, his own adaptation of The Second Shepherd's Play using kyōgen techniques, and Buffalo Bill's Well, an original play based on a Kansas legend and written by a student in the class that combined nō and kyōgen techniques. Buffalo Bill's Well has two main characters. One is the spirit of a Spanish Catholic priest, masked in the style of a shite character in $n \bar{o}$. The second, however, was not a typical no waki who is usually just a catalyst for the shite, but a living Buffalo Bill acted in kyogen style as comic antagonist to the priest. In a traditional performance kyogen is a compliment to $n \bar{o}$, but the characters from the two genres are never in conflict as was the case in Buffalo Bill's Well. Another notable attempt to fuse East and West for the university stage was a student-directed kyōgenstyle production of Moliere's Scapin in the fall of 1979.

Scapin was paired with The Ink-Smeared Lady (Suminuri), one of the many kyogen plays that Tsubaki translated and directed until his retirement in 2000. Over those years he staged a variety of nō, kyōgen, and fusion pieces in Greece, India, and Israel and throughout the United States. One huge benefit of being a student of Tsubaki's was to study with his masters in Japan. I was just one of his students to take lessons in $n \bar{o}$ from Nomura Shirō and in kyōgen from Nomura Mansaku. I learned the role of Tarōkaja, to Tsubaki-sensei's Master in the kyōgen Shimizu (Spring Water), for the 1983 Nomura Mansaku annual recital in Tokyo. I then repeated the role in 1985 in English at Kansas, and Tsubaki revived the play in later years.

In addition to the performances at the University of Kansas, we 
also took Shimizu on tour to the Nelson-Atkins Museum of Art in Kansas City, Missouri, in 1985. That performance and the many others Tsubaki arranged over the years at the Nelson were done with the cooperation and support of the Japanese Consul General in Kansas City. Those performances were one way for Tsubaki to bring traditional Japanese theatre and culture into the American heartland and nurture the cultural identity of the large Japanese-American community in the area.

At Association for Asian Performance and Association for Theatre in Higher Education conferences Tsubaki presented many papers on his activities in Japan. His constant conference contributions helped keep nō and kyogen in the sights of other Asian-performance scholars. His list of formal peer-reviewed publications is not long, and he never produced a monograph. However, his tireless efforts to learn every detail of $n \bar{o}$ and kyōgen plays are attested to by countless reels of eight-millimeter film and videotape, and a stack of almost thirty closely written training notebooks. All this was in an attempt to guide American students to full productions in the United States and elsewhere, and his is a remarkable legacy of practical theatre scholarship. It is that scholarship and teaching that connected students to a broader worldview of theatre-a contribution motivated by Andrew T. Tsubaki's own love of theatre.

\section{REFERENCES}

McKinnon, Richard N. 1951.

"Zeami on the Nō: A Study of 15th Century Japanese Dramatic Criticism." PhD dissertation, Harvard University.

Scott, Joseph W. 1949.

The Japanese Noh Play: The Essential Elements in its Theatre Art Form. PhD dissertation, Ohio State University.

Tsubaki, Andrew T. 1961.

"The Western Influence on the Development of Modern Theatre in Japan.” MA Thesis, Texas Christian University. 1971.

"Zeami and the Transition of the Concept of Yūgen: A Note on Japanese Aesthetics." Journal of Aesthetics and Art Criticism 30 (1): 55-67. 2001-2009.

"The Realties of Nōgaku Research in the U.S.A.: My Central Work of Directing $N \bar{o}$ and Kyogen, from the 1960s until the end of the 20th Century." Sōgōgeijutsu toshite no nō (Nō as a Comprehensive Art), vols. 7-14. Tokyo: Zeami Gakkai. 